\title{
Sensory acceptability and physical stability evaluation of a prebiotic soy-based dessert developed with passion fruit juice
}

\author{
Aceitação sensorial e avaliação da estabilidade física de uma sobremesa prebiótica à base de soja \\ desenvolvida com suco de maracujá
}

\author{
Daniel GRANATO ${ }^{1,2 *}$, Maria Lucia MASSON ${ }^{1}$, Jéssica Caroline Bigaski RIBEIRO³
}

\begin{abstract}
The aim of this study was to use a factorial design approach for developing a palatable and stable soy-based dessert with the addition of Soy Protein (SP), oligofructose, and Passion Fruit Juice (PFJ). Panelists $(\mathrm{n}=50)$ used a seven-point hedonic scale to assess the overall liking, degree of liking of creaminess, taste, and color of the desserts. In addition, the samples were submitted to a preference ranking test in order to evaluate the products' preference. Water Holding Capacity (WHC) and backscattering (BS) measures were also determined to assess the physical stability of the trials. Sample F3 (35\% PFJ and 2\% SP) was the only one that presented a WHC index of 94.8\%; moreover, none of the developed samples had synerisis after 72 hours of storage indicating adequate physical stability of the emulsion process. Samples F2 (25\% PFJ, and 3.0\% SP), F4 (35\% PFJ, and 3.0\% SP), and F5 (30\% PFJ, and 2.5\% SP) presented mean hedonic scores above 'slightly liked' for all sensory attributes. The acceptance index of samples varied from 62.50 to $88 \%$ showing the great sensory potential of such products.

Keywords: fructooligosaccharides; functional foods; soy-based desserts; acceptability; stability; fruit juices.
\end{abstract}

\section{Resumo}

Este trabalho objetivou desenvolver uma sobremesa com adição de Suco de Maracujá (SM), Proteína de Soja (PS) e oligofrutose que fosse estável e com sabor agradável, usando delineamento experimental. Provadores $(n=50)$ usaram uma escala hedônica de sete pontos para avaliar aceitação geral, cremosidade, sabor, e cor das amostras. Além disso, as sobremesas também foram avaliadas usando o teste de ordenação de preferência. Os índices de Capacidade de Retenção de Água (CRA) e sinérese (SN) foram determinados para avaliação da estabilidade física das amostras. A amostra F3 (35\% SM e 2\% PS) foi a única que apresentou índice de CRA de 94,8\%; não obstante, nenhuma amostra teve sinérese após 72 horas de estocagem refrigerada, mostrando um comportamento estável das amostras. As sobremesas F2 (25\% SM e 3,0\% PS), F4 (35\% SM e 3,0\% PS), e F5 (30\% SM e 2,5\% PS) obtiveram escores hedônicos acima de 'gostei ligeiramente' para todos os atributos sensoriais. Os índices de aceitação variaram de 62,50 a 88\%, mostrando grande potencial sensorial para tais produtos desenvolvidos. Palavras-chave: fruto-oligossacarídeos; alimentos funcionais; sobremesas à base de soja; aceitabilidade; estabilidade; sucos de frutas.

\section{Introduction}

The consumption of beverages and foods that are not produced with milk is a worldwide crescent trend (VERBEKE, 2005) once vegetarianism and diets with low contents of cholesterol, lipids, and energy have been adopted by consumers. Current industrial dessert products are basically milk-based, which may represent inconveniences due to their lactose and cholesterol contents (HEENAN et al., 2004). However, technological advances have made it possible to alter some structural characteristics of matrices by modifying food components in a controlled way and also by replacing milk with other by-products derived from oat, soy, fruits, and other vegetables, which have been extensively studied to develop novel good-looking and palatable foods (CHEN; WEINGARTNER; BREWER, 2003; PINTO et al., 2003; IZIDORO et al., 2008).

Non-dairy products have shown a great sensory appeal (SOLER, 2005; POTTER et al., 2007; GRANATO et al., 2010a; BRANCO et al., 2010) and market potential worldwide due to a high percentage of population that present lactose-intolerance. The Brazilian industry produced a total of 22 million tons of many types of desserts in 2008, including milk-based and soy-based foods, which generated a total of $\mathrm{R} \$ 200$ million; this increase in sales is probably due to an ongoing investment to launch different palatable products in the Brazilian market (REVISTA..., 2008). Since soybean production is relatively cheap in Brazil, the use of soy protein in the development of new foods can be an inexpensive way to increase the number of soycontaining products in the market place and facilitate a higher ingestion of protein and minerals in the regular diet. Moreover, soybeans contain $\beta$-sitosterol, campesterol, and stigmasterol, sterols with recognized serum cholesterol-lowering properties (NORMÉN et al., 2000).

The market demand for new low-cost nourishing products has encouraged researchers to study different ingredients to produce stable and palatable foods. Accordingly, many types of

${ }^{1}$ Programa de Pós-graduação em Engenharia de Alimentos, Universidade Federal do Paraná - UFPR, Curitiba, PR, Brasil, e-mail: mestradoalimentos@gmail.com

2 Departamento de Biomedicina e Ciências Biológicas, Centro Educacional das Faculdades Metropolitanas Unidas, São Paulo, SP, Brasil

3 Departamento de Engenharia de Alimentos, Universidade Estadual de Ponta Grossa - UEPG, Ponta Grossa, PR, Brasil

${ }^{*}$ Corresponding author 
desserts have been developed towards this end, such as aerated dairy dessert with passion fruit juice (PINTO et al., 2003), frozen blueberry-soy based dessert (TEH; DOUGHERTY; CAMIRE, 2005), non-dairy frozen dessert containing soy protein and coconut milk (SOLER, 2005), non-dairy corn-based dessert (SOUZA; MIRANDA, 2008), dairy dessert with addition of soy extract and chocolate (VIEIRA et al., 2008), and soy-based dessert with guava juice and oligofructose (GRANATO et al., 2010a).

In the last decade, food industries has begun to explore more rigorously the use of dietary fibers such as inulin and oligofructose, which are non-digestible fermentable fructose containing polymers, and because they are among the most studied prebiotic fibers (GIBSON et al., 2004). In vitro and in vivo studies have shown that these compounds have many beneficial physiological effects on human's health, such as helping manage constipation (DEN HOND; GEYPENS; GHOOS, 2000), improving the composition of intestinal flora (GIBSON et al., 2004), and bone mineralization (BOSSCHER; van LOO; FRANCK, 2007). Thus, the addition of oligofructose - one of the cheapest dietary fiber - in food products seems to be a good way to boost consumers' health and to increase fiber ingestion.

Soy-containing products have been optimized in order to improve taste, appearance, and flavor, and also to address and dissipate consumers' negative opinions regarding these foods (BEHRENS; ROIG; SILVA, 2004; TEH; DOUGHERTY; CAMIRE, 2005; GRANATO et al., 2010a). In addition, there is no report on sensory evaluation of soy-based desserts made with soy protein, yellow passion fruit juice, and oligofructose; hence this study was aimed at the development of stable palatable desserts made with soy protein and yellow passion fruit juice supplemented with oligofructose. Sensory evaluation and physical stability tests were also carried out in order to accomplish this objective.

\section{Material and methods}

\subsection{Materials}

The ingredients used in the formulations included soy protein $(2.0,2.5$ or $3.0 \%)$ derived from a water soluble extract, commercial sucrose $(13 \% \mathrm{w} / \mathrm{w})$, a pool of emulsifiers $(0.5 \%$ w/w, with distillated monoglycerides, polysorbate 60 , and sorbitane monoesterate), guar gum and carboximethylcelullose in a $1: 1$ ratio $(0.5 \% \mathrm{w} / \mathrm{w})$, passion fruit natural flavoring $(0.15 \%$ $\mathrm{w} / \mathrm{w})$, soy cream $(35 \% \mathrm{w} / \mathrm{w}$, with $18.67 \% \mathrm{w} / \mathrm{w}$ of total lipids), oligofructose $(2.63 \%$, with $95 \%$ purity), yellow passion fruit juice (made with $50 \%$ of pulp in water: $\mathrm{pH}=2.63$, ${ }^{\circ} \mathrm{Brix}=8.20$, acidity $=4.55 \%$ in citric acid; used in a proportion of 25,30 , or $35 \% \mathrm{w} / \mathrm{w})$, and passion fruit juice powder $(3.0 \% \mathrm{w} / \mathrm{w})$. Water was added to make up to $100 \%$ of the total.

\subsection{Experimental design and production of samples}

The study was conducted according to the methods of Box and Drapper (1987) using a factorial design $\left(2^{2}\right)$ adding 1 centre point to the experiment. The complete design consisted of pilot-scale soy-based desserts denoted F1, F2, F3, F4, and F5, as observed in Table 1. Two independent variables were employed: yellow Passion Fruit Juice (PFJ) and Soy Protein (SP). The minimum, mean, and maximum levels of passion fruit juice concentration were set to 25,30 , and $35 \%(w / w)$, respectively; for soy protein they were set to $2.0,2.5$, and $3.0 \%$ $(\mathrm{w} / \mathrm{w})$, respectively. The levels of the independent variables were based on preliminary studies.

Each lot of soy-based dessert was produced at large enough scale to obtain $3.0 \mathrm{~kg}$ of the final product. For this purpose, after weighing all the ingredients individually, they were all mixed for 3 minutes, except for the emulsifying agent, and were heated up to $80^{\circ} \mathrm{C}$ in a water-bath for 20 seconds. Next, they were cooled

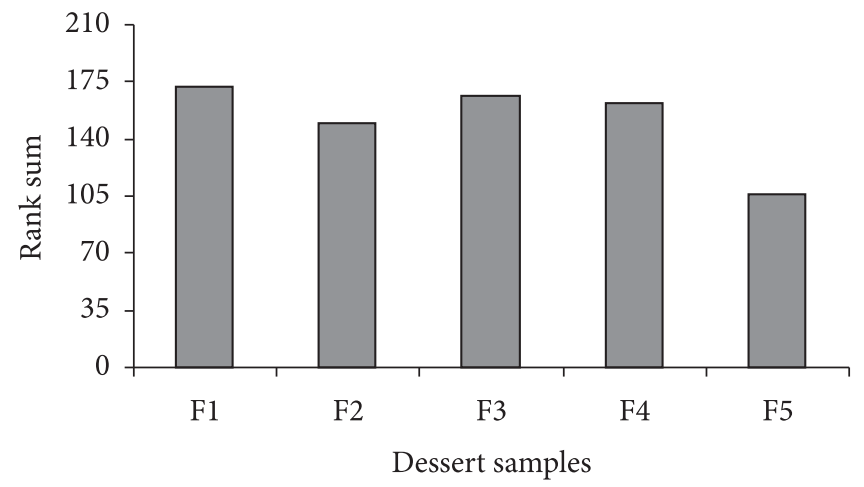

Figure 1. Rank sum scores for the soy-based desserts. Lower rank sum scores indicate higher overall preference and higher rank sum scores indicate lower preference. If samples share the same letter, they are not significantly different at $5 \%$ level of significance according to the Friedman test. See Table 1 for definition of sample abbreviations.

Table 1. Sensory data for soy-based desserts produced with passion fruit juice and oligofructose.

\begin{tabular}{|c|c|c|c|c|c|c|c|c|}
\hline \multirow[t]{2}{*}{ Sample } & \multicolumn{2}{|c|}{ Coded matrix } & \multicolumn{2}{|c|}{ Decoded matrix } & \multicolumn{4}{|c|}{ Sensory attributes } \\
\hline & PFJ & SP & $\mathrm{PFJ}$ & SP & Taste & Creaminess & Color & Overall liking \\
\hline F1 & -1 & -1 & 25 & 2.0 & $4.48(0.39)$ & $4.32^{\mathrm{c}}(0.69)$ & $4.44^{\mathrm{b}}(0.66)$ & $4.52^{\mathrm{c}}(0.57)$ \\
\hline F2 & -1 & 1 & 25 & 3.0 & $5.12(0.87)$ & $5.48^{\mathrm{a}, \mathrm{b}}(0.52)$ & $5.68^{\mathrm{a}}(0.63)$ & $5.36^{\mathrm{a}, \mathrm{b}}(0.80)$ \\
\hline $\mathrm{F} 4$ & 1 & 1 & 35 & 3.0 & $5.04(0.48)$ & $5.36^{\mathrm{a}, \mathrm{b}}(0.75)$ & $5.04^{\mathrm{a}, \mathrm{b}}(0.71)$ & $5.08^{\mathrm{a}, \mathrm{b}}(0.62)$ \\
\hline \multirow[t]{4}{*}{ F5 } & 0 & 0 & 30 & 2.5 & $5.56(0.62)$ & $5.72^{\mathrm{a}}(0.60)$ & $5.60^{\mathrm{a}}(0.58)$ & $5.52^{\mathrm{a}}(0.67)$ \\
\hline & \multicolumn{4}{|c|}{$\mathrm{p}_{\text {sample }}(\text { Hartley })^{1}$} & 0.08 & 0.19 & 0.36 & 0.22 \\
\hline & \multicolumn{4}{|c|}{$\mathrm{p}_{\text {panelists }}(\text { Hartley })^{1}$} & 0.88 & 0.08 & 0.99 & 0.10 \\
\hline & \multicolumn{4}{|c|}{$\mathrm{p}_{\text {panelists }}(\text { Anova })^{2}$} & 0.06 & 0.12 & 0.07 & 0.09 \\
\hline
\end{tabular}

PFJ, passion fruit juice; SP, soy protein; ${ }^{1}$ Probability value obtained by Hartley test (F max) for homogeneity of variances; ${ }^{2}$ Probability value obtained by two-way ANOVA. 
and homogenized following the addition of the emulsifying agent. The mixture was blended using a mixer at $20^{\circ} \mathrm{C}$ for 4 minutes. The product was packaged aseptically in individual plastic cups, each one containing $50 \mathrm{~g}$ of dessert, sealed with a plastic cover, and stored in a refrigerator at $7 \pm 1^{\circ} \mathrm{C}$. In order to be considered a source of fiber, food products marketed in Brazil must contain at least $2.5 \%$ of their total weight in fiber; therefore, oligofructose was also added to the samples at a concentration of $2.5 \%$ of the total weight, considering its purity of $95 \%$.

\subsection{Microbiological evaluation}

For the microbiological assessments, $25 \mathrm{~g}$ of sample were added to $225 \mathrm{~mL}$ of sterile peptone water and blended in a Stomacher bag for 1 minute. Aliquots were serially diluted with sterile $0.1 \%$ peptone water and pour plated. The samples were examined for total coliforms, thermotolerant coliforms, Staphylococcus aureus, Bacillus cereus, Salmonella sp., total mold, and yeast counts in agreement with the procedure described by American Public Health Association (AMERICAN..., 2001) and recommended by the Brazilian legislation (BRASIL, 2001). All of the results were expressed in CFU.g ${ }^{-1}$ or MPN.g ${ }^{-1}$, and Salmonella sp. was expressed as 'absent' in $25 \mathrm{~g}$.

\subsection{Sensory evaluation}

The dessert samples were analyzed for color, creaminess, taste, and overall liking after overnight storage at $4-5^{\circ} \mathrm{C}$ using two methods: the rating test (method 1) and the preferenceranking test (method 2). Fifty untrained panelists, who declared themselves regular consumers of desserts/soy products, were asked to rate the samples on the basis of a 7-point hedonic scale anchored by: 1 = 'Strongly disliked'; 2 = 'Moderately disliked'; 3 = 'Slightly disliked'; 4 = 'Indifferent'; 5 = 'Slightly liked'; 6 = 'Moderately liked', and 7 = 'Strongly liked' (GRANATO et al., 2010a). The samples were presented monadically following a completely randomized design. Mineral water and cream cracker biscuits were available as neutralizers between samples in order to avoid carryover effects.

Taste preference was evaluated using the ranking test according to the subjects' degree of liking. A sample ballot for a ranking test of five products was adopted. A variation on this ballot lists the ranks from $1=$ most preferred to $5=$ least preferred (LAWLESS; HEYMANN, 1999). The subjects were instructed to taste dessert samples and rank them according to the first sensory impression and re-test to be certain of the correct ranking.

Prior to each assessment, the subjects were informed about the task for each of the two methods. In addition to the oral information, a detailed set of written instructions on the testing methods was available in each booth. A total of $50 \mathrm{~mL}$ of each dessert at $7^{\circ} \mathrm{C}$ was served to each subject in coded opaque plastic tumblers. The tests were performed in the sensory laboratory under conditions of standard light and temperature $\left(20^{\circ} \mathrm{C}\right)$ with groups of 5 subjects, each placed in individual booths.

\subsection{Evaluation of physical stability}

Physical stability is generally related to the shelf life of emulsion systems, such as ice creams, puddings, creams, and other desserts when only gravitational forces are considered. Mittall (1971) proposed that an emulsion could be either reversibly or irreversibly physically unstable. Reversible instability can be subdivided into sedimentation and flocculation. Irreversible instability is indicated by coalescence, demulsification, and inversion. In this study, two methods of dessert evaluation were used: the measurement of water holding capacity and backscattering.

\section{- Water holding capacity (WHC)}

The water holding capacity (WHC) of the soy-based desserts was determined in triplicate by a method reported earlier (HARTE et al., 2003) with slight modifications. A sample of about $20 \mathrm{~g}$ of dessert (DE) was put in a cylindrical glass measurement cell and centrifuged for 40 minutes at $5000 \mathrm{rpm}$ at an average temperature of $5^{\circ} \mathrm{C}$. The whey expelled (WE) was removed and weighed. The WHC, expressed in \%, was defined as: $\mathrm{WHC}=100[(\mathrm{DE}-\mathrm{WE}) / \mathrm{DE}]$.

- Backscattering (BS)

Freshly prepared desserts $(20 \mathrm{~g})$ were transferred into cylindrical tubes (internal diameter $15 \mathrm{~mm}$, height $120 \mathrm{~mm}$ ), capped, and stored at $5 \pm 1{ }^{\circ} \mathrm{C}$ for 72 hours. After storage, the samples were assessed for stability by measuring the total height of the dessert (HE) and the height of the clear serum layer (HS) that may have formed after storage. The backscattering under refrigeration was determined in triplicate in accordance with White et al. (2008): $\mathrm{BS}=100$ (HS/HE).

\subsection{Statistical analysis}

Data are reported as mean \pm SD. Firstly, the Hartley test was used to check the homogeneity of the variances. Two-way ANOVA was then carried out for the rating test data to determine the overall significance of the main effects and interactions between the dessert samples $(n=5)$ and panelists $(n=50)$, followed by the parametric Tukey's Honest Significant Difference test. A p-value below 0.05 was considered statistically significant. The acceptance index of each dessert sample was calculated by the percentage of respondents who indicated that they 'slightly liked', 'moderately liked', or 'strongly liked' the product (GRANATO; ELLENDERSEN, 2009). Pearson's correlation coefficients (r) were calculated for the determination of correlations among the sensory attributes (GRANATO et al., 2010b).

Ranking data were analyzed by the non-parametric Friedman analysis of variance in order to verify the existence of significant differences in preference among the samples (LAWLESS; HEYMANN, 1999). The statistical method proposed by Conover (1999) was used to identify the samples that differed among themselves at $5 \%$ of significance.

\section{Results and discussion}

Non-dairy products have a big worldwide importance due to the ongoing trend of vegetarianism and to a high prevalence of lactose intolerance in many populations around the world (BRANCO et al., 2010). Lactose intolerance consists 
of the absence of lactase production, which is responsible for hydrolyzing the lactose present in dairy products. In accordance with Alm (2002), in Northern Europe, the number of lactoseintolerant individuals is around 5\%; in some African countries it reaches $90 \%$, while in the Unites States of America it is around $30 \%$ of the adult population in Brazil although a few studies have found an incidence of lactose intolerance between 46 and $67 \%$. In this regard, we attempted to develop a milk-free dessert with added oligofructose that presented a high sensory acceptance and a remarkable physical stability, which represent two main features of this type of food.

\subsection{Microbiological and stability evaluations}

In accordance with the Brazilian legislation, all the samples showed low counts of total coliforms and thermotolerant coliforms $\left(<3 \mathrm{MPN} \cdot \mathrm{g}^{-1}\right)$, Staphylococcus aureus $\left(<10^{2} \mathrm{MPN} \cdot \mathrm{g}^{-1}\right)$, Bacillus cereus $\left(<10^{2} \mathrm{MPN} \cdot \mathrm{g}^{-1}\right)$, molds and yeasts $\left(<10^{2} \mathrm{CFU} \cdot \mathrm{g}^{-1}\right)$, and they did not contain Salmonella sp. in $25 \mathrm{~g}$ (BRASIL, 2001). It can be concluded that the samples were microbiologically safe for sensory assessment.

Only the sample F3 (35\% PFJ and 2\% SP) dessert presented a WHC index of $94.8 \%$. All other samples presented a value of $\mathrm{WHC}=100 \%$, holding all the non-chemically bound water in the food matrix, and thus they did not present any instability in response to gravity. Notwithstanding, the samples did not present an aqueous layer at the bottom of the glass tubes and did not present backscattering after centrifugation $(\mathrm{BS}=0 \%)$. These results may be due to one main reason: storage at low temperatures makes proteins from the oil/ water interface increase the number of interactions among the droplets promoting the development of a three-dimensional connective network among the proteins, which would have eventually prevented coalescence. Nevertheless, the coalescence mechanism seems to be limited to the first storage stage (48 hours) after emulsification (PALAZOLO; SORGENTINI; WAGNER, 2005).

Salep, a natural stabilizing agent widely used in ice cream and some dairy and non-dairy desserts, significantly increased water holding capacity in a non-dairy dessert (AYAR; SERT; AKBULUT, 2009). Petit-suisse cheeses marketed in Brazil present a water holding capacity in the range of $40.46-92.38 \%$, and this remarkable difference is mainly due to technological unit operations used to produce such products (VEIGA et al., 2000). Granato et al. (2010a) developed soy-based desserts with the addition of oligofructose and different concentrations of guava juice $(22,27$, and $32 \%)$ and soy protein $(1,2$, and $3 \%)$ and found that only the sample containing $27 \%$ of guava juice and $1 \%$ of soy protein had whey formation after centrifugation (7.0\%), while all other desserts presented $\mathrm{WHC}=100 \%$ and $\mathrm{BS}=0 \%$ after 72 hours of refrigeration additionally; a dessert developed with $32 \%$ of red guava juice and $2 \%$ of soy protein was evaluated in terms of sensory characteristics, instrumental color, microbiological parameters, physical stability, and ascorbic acid content; the estimated shelf-life of such product was 79 days (GRANATO; FREITAS; MASSON, 2010). Soyyogurts showed similar low values of syneresis, which ranged between 2 and 7\% of whey expulsion (CRUZ et al., 2009). Kovalenko and Briggs (2002) showed 84.1-96\% of WHC in soy-based desserts. These data indicate that soy-based emulsions produced with soy protein, fruit juice, and oligofructose are stable under refrigeration, which is a favorable characteristic if logistics in food distribution and product appearance are taken into consideration.

\subsection{Sensory assessment}

Friedman's analysis of variance showed that the overall perception of quality among the samples were not significantly different (Figure 1). However, sample F5 (30\% PFJ and 2.5\% SP) presented the lowest rank sum, and thus the highest preference. On the other hand, F1 (25\% PFJ and 2.0\% SP) showed the highest rank sum, which indicates the least preference. When no differences among samples are obtained using the ranking test, analysis of other individual sensory attributes such as degree of liking and acceptability may be required in order to obtain the representative sample of the experiment (ARAYA et al., 2009). Moreover, the preference ranking test does not explain why a certain formulation is preferred over the others. In this regard, a rating test can be performed with the same subjects to verify which attribute is higher/lower in each formulation, and therefore a sensory optimization can be made.

Using the rating test, significant differences $(\mathrm{p}<0.05)$ were observed for degree of liking of creaminess, color, and, overall liking among samples (Table 1). In addition, there was a consensus among panelists in accordance with the the variance analysis $\left(\mathrm{p}_{\text {panelists }} \geq 0.06\right.$ ), and the hedonic scores seemed to be homogenous when the Hartley test was applied $\left(\mathrm{p}_{\text {samples }} \geq 0.08\right)$. Checking for homogeneity of variances in sensory analysis is essential in order to evaluate statistical robustness of data.

Only samples F2 (25\% PFJ and 3.0\% SP), F4 (35\% PFJ and $3.0 \% \mathrm{SP}$ ), and $\mathrm{F} 5$ ( $30 \% \mathrm{PFJ}$ and $2.5 \% \mathrm{SP}$ ) presented mean scores above 5.00 (slightly liked) for all attributes evaluated. On the other hand, sample F1 (25\% PFJ and 2.0\% SP) garnered the lowest mean scores for those attributes. Samples that presented scores below 'slightly liked' - F1 and F3 - cannot be considered as potentials for market purposes.

The degree of liking of color varied significantly $(\mathrm{p}<0.001)$, and the samples made with $35 \%$ of PFJ (F3 and F4) did not garner the highest mean scores. However, sample F1 (25\% PFJ, $2 \%$ SP) seemed to be the least preferred by the taste panel for presenting an unacceptable mean score (4.44); while the other samples obtained mean scores within the acceptability range (5.00-7.00). In food products, especially fruit-based ones, the consumer often assesses the initial quality by their color and appearance; hence these attributes are the primary indicators of perceived quality (LAWLESS; HEYMANN, 1999). Moreover, color is a parameter for consideration for novel foods due to their initial acceptability by potential consumers, and color also determines purchase and regular consumption of products (TARREGA; COSTELL, 2007).

The overall liking of samples ranged from 4 (indifferent) to 6 (moderately liked), and the sample F5 (30\% PFJ and 
$2.5 \% \mathrm{SP}$ ) garnered the highest mean score (5.52). However, only sample F1 (25\% PFJ and 2.0\% SP) did not garner an acceptable score $(4.52)$ and differed statistically $(\mathrm{p}<0.05)$ from the other formulations. Overall liking was strongly correlated to taste $(\mathrm{r}=0.817 ; \mathrm{p}<0.05)$ and color $(\mathrm{r}=0.971 ; \mathrm{p}<0.05)$ contributing to the idea that both taste and color are two main drivers to food initial acceptance. Desserts developed with organic soy water-soluble extract and chocolate were well accepted by consumers by presenting overall liking in the range 6.25-7.25 (VIEIRA et al., 2008), both using a nine-point hedonic scale. A high-fiber dessert elaborated with corn pulp supplemented with $7.5 \%$ of inulin and $7.2 \%$ of oligofructose obtained high hedonic scores for taste (7.00), color (8.00), and creaminess (6.00) (SOUZA; MIRANDA, 2008). These findings indicate that desserts elaborated with non-dairy ingredients present suitable sensory scores and a high acceptance, and therefore need to be extensively explored by food industries in order to offer new palatable options for lactose-intolerant or cow protein-allergic consumers.

Creaminess mean scores ranged statistically $(\mathrm{p}<0.001)$ from 4.32 to 5.72, mainly due to the concentration of watersoluble extract employed in the formulations. The findings of some studies have supported the case that a positive linear relationship does exist between overall liking and creaminess attributes (RICHARDSON-HARMAN et al., 2000; GRANATO et al., 2010a). A study that examined Japanese and Australian consumer perceptions for frozen dessert that varied in fat content found that 'overall liking' and 'liking of creaminess' were closely related (PRESCOTT et al., 1997). In this study, the degree of liking of creaminess was strongly correlated to overall liking $(\mathrm{r}=0.899 ; \mathrm{p}<0.05)$ showing that creaminess is a good indicator of quality for soy-based dessert. This result indicates that food producers must consider it when new product development is required. Elmore et al. (1999) varied the amount and type of starch, amount of milk fat, and sodium salts in puddings and found that hedonic scores for creamy texture were higher for puddings that were perceived as thicker, more visually airy, more mouth coating, denser, and slower melting.

There was not a significant statistical difference $(p=0.08)$ in liking of taste among the samples. The mean scores were in the range $4.48-5.56$, and only F1 (25\% PFJ and $2.0 \% \mathrm{SP}$ ) and F3 (25\% PFJ and 3.0\% SP) did not get acceptable scores (4.48 and 4.72 , respectively). Soy products usually present astringent flavor, and that is why many products are not well-accepted by consumers (BEHRENS; SILVA, 2004). In this study, it was verified that even high concentrations of soy protein did not alter significantly the taste and overall liking of the desserts. Nikaedo, Amaral and Penna (2004) developed creamy chocolate dairy desserts and encountered taste scores ranging from 3.47 to 4.30 using a rating test with a five-point scale.

The acceptance index of samples varied from 62.50 to $88 \%$ (Figure 2), showing a great sensory potential of such products. Sample F2 (25\% PFJ and 3\% SP) received the highest index $(88 \%)$ and F1 (25\% PFJ and 2\% SP) the lowest index (62.5\%). These data corroborate earlier observations that higher concentrations of soy protein promote higher acceptance index of desserts elaborated with fruit juices (GRANATO et al., 2010a).

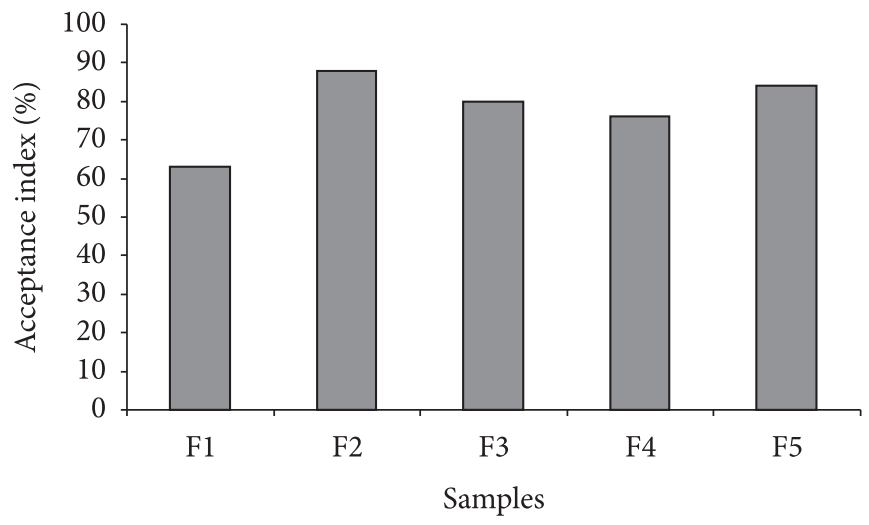

Figure 2. Percentage of respondents that indicated that they 'slightly liked', 'moderately liked', or 'strongly liked' the soy-based desserts. See Table 1 for definition of sample abbreviations.

A chocolate custard non-dairy dessert using with rice flour was developed, and the authors found an acceptance index of $86 \%$, which was not significantly different from a milk-based commercial product (DORS; CASTIGLIONI; RUIZ, 2006). The acceptance index of foods is taken into consideration when new ingredients are added or the formulation is optimized, and it reflects the degree of liking or disliking for a food product, which in turn is used to predict acceptability. However, in food industries, acceptance solely is not the only parameter to be analyzed in order to launch the product; other attributes such as taste, color, appearance, acidity, sweetness, price, physical stability, and nutritional composition also play an important role.

Walker (2002) evaluated the sensory attributes of an orange sherbet, a commonly consumed dessert in Europe and in the United States, and found hedonic scores above 7.00 (moderately liked) for degree of liking of color and overall liking, and unacceptable scores (below 6.00) for creaminess of samples that contained texturized soy protein between 3.25 and $6.25 \%$. The authors suggested that high soy protein products enhance an astringent ('beany') flavor and hence may have influenced negatively consumers rating. Creamy chocolate or vanilla desserts, containing $2 \%$ of soy protein, presented an acceptance index of $78 \%$, and mean hedonic scores in the range 6.85-8.31 for taste, 7.30-8.20 for flavor, 7.5-8.5 for creaminess, and 7.6-8.3 for color using a nine-point hedonic scale (CHAVES; MATTÉ; MENDONÇA, 2007).

\section{Conclusions}

From the linear correlation analysis, it can be concluded that solely overall liking of soy-based desserts should be assessed in the rating test in order to indicate the degree of liking for the product samples since strong and significant correlation among all the other parameters was obtained. Samples F2 (25\% PFJ and $3.0 \% \mathrm{SP}), \mathrm{F} 4$ (35\% PFJ and 3.0\% SP), and F5 (30\% PFJ and $2.5 \% \mathrm{SP}$ ) presented mean scores above 5.00 (slightly liked) for all attributes evaluated and a higher preference in accordance with the ranking test. These data indicate that a dessert developed with soy protein, oligofructose, and passion fruit juice presents sensory appeal and has the potential to be commercialized. 


\section{Acknowledgements}

The authors are grateful for the financial support provided by CAPES (Brazilian research supporting foundation).

\section{References}

ALM, L. Lactose intolerance. In: ROGINSKY, H.; FUQUAY, J. W.; FOX, P. F. (Eds.). Encyclopedia of dairy sciences. London: Academic Press, 2002. p.1533-1537.

AMERICAN PUBLIC HEALTH ASSOCIATION - APHA. Compendium of methods for the microbiological examination of foods. 4. ed. Washington: APHA, 2001. 676 p.

ARAYA, X. I. T. et al. Sensory perception and quality attributes of high pressure processed carrots in comparison to raw, sous-vide and cooked carrots. Innovative Food Science Emerging, v. 10, n. 4, p. 420-433, 2009.

AYAR, A.; SERT, D.; AKBULUT, M. Effect of salep as a hydrocolloid on storage stability of Incir Uyutmasi dessert. Food Hydrocolloids, v. 23, n. 1, p. 62-71, 2009. http://dx.doi.org/10.1016/j.foodhyd.2007.11.014

BEHRENS, J. H.; SILVA, M. A. A. P. Atitude do consumidor em relação à soja e produtos derivados. Ciência e Tecnologia de Alimentos, v. 24 , n. 3, p. 431-439, 2004. http://dx.doi.org/10.1590/S010120612004000300023

BEHRENS, J. H.; ROIG, S. M.; SILVA, M. A. A. P. Fermentation of soymilk by commercial lactic cultures: development of a product with market potential. Acta Alimentaria, v. 33, n. 2, p. 101-109, 2004. http://dx.doi.org/10.1556/AAlim.33.2004.2.2

BOX, G. E. P.; DRAPPER, N. Empirical model-building and response surface. New York: John Wiley, 1987. 669 p.

BOSSCHER, D.; van LOO, J.; FRANCK, A. Inulin and oligofructose as functional ingredients to improve bone mineralization. International Dairy Journal, v. 16, n. 9, p. 1092-1097, 2007. http:// dx.doi.org/10.1016/j.idairyj.2005.10.028

BRANCO, G. F. et al. Functional foods and non-dairy probiotic product food development: trends, concepts and products. Comprehensive Reviews in Food Science and Food Safety, v. 9, p. 292-302, 2010.

BRASIL. Ministério da Saúde. Secretaria Nacional de Vigilância Sanitária. Resolução - RDC n 12, de 02 de janeiro de 2001. Regulamento técnico sobre padrões microbiológicos para alimentos. Diário Oficial da República Federativa do Brasil, Brasília, DF, jan. 2001. 20 p.

CHAVES, M. A.; MATTÉ, G. M.; MENDONÇA, S. N. T. G. Avaliação microbiológica e sensorial de sobremesa cremosa à base de extrato aquoso de soja adicionado de Lactobacillus acidophillus. In: ENCONTRO REGIONAL SUL DE CIÊNCIA E TECNOLOGIA DE ALIMENTOS, 9., Curitiba, 2007. Anais... Curitiba, 2007. p. 293-297.

CHEN, D. J.; WEINGARTNER, K.; BREWER, M. S. Consumer evaluation of soy ingredient-containing cookies. Journal of Food Quality, v. 26, n. 3, p. 219-229, 2003. http://dx.doi. org/10.1111/j.1745-4557.2003.tb00240.x

CONOVER, W. J. Practical nonparametric statistics. 3. ed. New York: John Wiley \& Sons, 1999. 578 p.

CRUZ, N. S. et al. Soymilk treated by ultra high-pressure homogenization: Acid coagulation properties and characteristics of a soy-yogurt product. Food Hydrocolloids, v. 23, n. 2, p. 490-496, 2009. http:// dx.doi.org/10.1016/j.foodhyd.2008.03.010
DEN HOND, E. M.; GEYPENS, B. J.; GHOOS, Y. F. Effect of long chain chicory inulin on bowel habit and transit time in constipated persons. Nutrition Research, v. 20, n. 1, p. 731-736, 2000.

DORS, G. C.; CASTIGLIONI, G. L.; RUIZ, W. A. Utilização da farinha de arroz na elaboração de sobremesa. Vetor, v. 16, n. 1-2, p. 63-67, 2006.

ELMORE, J. R. et al. Preference mapping: relating acceptance of 'creaminess' to a descriptive map of a semi-solid. Food Quality and Preference, v. 10, n. 6, p. 465-475, 1999. http://dx.doi.org/10.1016/ S0950-3293(99)00046-4

GIBSON, G. R. et al. Dietary modulation of the human colonic microbiota: updating the concept of prebiotics. Nutitrion Research Reviews, v. 17, n. 1, p. 259-275, 2004. PMid:19079930. http://dx.doi. org/10.1079/NRR200479

GRANATO, D.; FREITAS, R. J. S.; MASSON, M. L. Stability studies and shelf life estimation of a soy-based dessert. Ciência e Tecnologia de Alimentos, v. 30, p. 797-807, 2010.

GRANATO, D. et al. Physical stability assessment and sensory optimization of a dairy-free emulsion using response surfacemethodology. Journal of Food Science, v. 73, p. 149-155, 2010a. PMid:20492311. http:// dx.doi.org/10.1111/j.1750-3841.2010.01514.x

GRANATO, D. et al. Sensory evaluation and physicochemical otimisation of soy-based desserts using response surface methodology. Food Chemistry, v. 121, p. 899-906, 2010b. http:// dx.doi.org/10.1016/j.foodchem.2010.01.014

GRANATO, D.; ELLENDERSEN, L. S. N. Almond and peanut flours suppelmented with iron as potential ingredients to develop gluten-free cookies. Ciência e Tecnologia de Alimentos, v. 29, p. 395-400, 2009. http://dx.doi.org/10.1590/S0101-20612009000200026

HARTE, F. et al. Low-fat set yogurt made from milk subjected to combinations of high hydrostatic pressure and thermal processing. Journal of Dairy Science, v. 86, n. 4, p. 1074-1082, 2003. http:// dx.doi.org/10.3168/jds.S0022-0302(03)73690-X

HEENAN, C. N. et al. Survival and sensory acceptability of probiotic microorganisms in a nonfermented frozen vegetarian dessert. Food Science and Technology, v. 37, n. 4, p. 361-366, 2004.

IZIDORO, D. R. et al. Influence of green banana pulp on the rheological behaviour and chemical characteristics of emulsions (mayonnaises). LWT - Food Science and Technology, v. 41, n. 6, p. 1018-1028, 2008.

KOVALENKO, I. V.; BRIGGS, J. L. Textural characterization of soybased yogurt by the vane method. Journal of Texture Studies, v. 33, n. 2, p. 105-118, 2002. http://dx.doi.org/10.1111/j.1745-4603.2002. tb01338.x

LAWLESS, H. T.; HEYMANN, H. Sensory evaluation of food: principles and practices. Gaithersburg: Aspen Publishers, 1999. 827 p.

MITTALL, K. L. Conceptual clarification of the terms used to describe emulsion behavior. Journal of Cosmetology Chemistry, v. 22, p. $815-817,1971$.

NIKAEDO, P. H. L.; AMARAL, F. F.; PENNA, A. L. B. Caracterização tecnológica de sobremesas lácteas achocolatadas cremosas elaboradas com concentrado protéico de soro e misturas de gomas carragena e guar. Brazilian Journal of Pharmaceutical Sciences, v. 40, n. 3, p. 397-404, 2004.

NORMÉN, L. et al. Soy sterol esters and ß-sitostanol ester as inhibitors of cholesterol absorption in human small bowel. American Journal of Clinical Nutrition, v. 71, n. 4, p. 908-913, 2000.

PALAZOLO, G. G.; SORGENTINI, D. A.; WAGNER, J. R. Coalescence and flocculation in $\mathrm{o} / \mathrm{w}$ emulsions of native and denatured whey soy proteins in comparison with soy protein isolates. 
Food Hydrocolloids, v. 19, n. 3, p. 595-604, 2005. http://dx.doi. org/10.1016/j.foodhyd.2004.10.022

PINTO, E. P. et al. Sucralose no desenvolvimento de sobremesas lácteas light. Boletim do Centro de Pesquisa e Processamento de Alimentos, v. 21, n. 1, p.49-60, 2003.

POTTER, R. M. et al. Characteristics of wild blueberry-soy beverages. LWT - Food Science and Technology, v. 40, n. 5, p. 807-814, 2007.

PRESCOTT, J. et al. Cross-cultural comparisons of Japanese and Australian responses to manipulations of sweetness in foods. Food Quality and Preference, v. 8, n. 1, p. 45-55, 1997. http://dx.doi. org/10.1016/S0950-3293(96)00006-7

REVISTA BRASIL ALIMENTOS. Sobremesas. 2008. Disponível em: <http://www.brasilalimentos.com.br/BA/default.asp?COD=3201\& busca $=$ sobremesa\&numero $=390>$. Acesso em: 13 abr. 2009.

RICHARDSON-HARMAN, N. J. et al. Mapping consumer perceptions of creaminess and liking for liquid dairy products. Food Quality and Preference, v. 11, p. 239-246, 2000. http://dx.doi.org/10.1016/ S0950-3293(99)00060-9

SOLER, L. Development of non-dairy frozen emulsion containing soy protein and coconut milk. 2005. 84 f. Tese (Doutorado)Louisiana State University and Agricultural and Mechanical College, Louisiana, 2005.

SOUZA, T. L. A.; MIRANDA, C. F. Desenvolvimento da mousse de milho verde diet com ingredientes funcionais. In: CONGRESSO BRASILEIRO DE CIÊNNCIA E TECNOLOGIA DE ALIMENTOS, 21., 2008, Belo Horizonte. Anais... Belo Horizonte, 2008.
TARREGA, A.; COSTELL, E. Color and consistency of semi-solid dairy desserts: Instrumental and sensory measurements. Journal of Food Engineering, v. 78, n. 2, p. 655-661, 2007. http://dx.doi. org/10.1016/j.jfoodeng.2005.11.003

TEH, Y-H.; DOUGHERTY, M. P.; CAMIRE, M. E. Frozen blueberry-soy emulsion quality. Journal of Food Science, v. 70, n. 2, p. 119-122, 2005. http://dx.doi.org/10.1111/j.1365-2621.2005.tb07115.x

VEIGA, P. G. et al. Caracterização química, reológica e aceitação sensorial do queijo petit suisse brasileiro. Ciência e Tecnologia de Alimentos, v. 20, n. 3, p. 349-357, 2000. http://dx.doi.org/10.1590/ S0101-20612000000300012

VERBEKE, W. Consumer acceptance of functional foods: Sociodemographic cognitive and attitudinal determinants. Food Quality and Preference, v. 16, n. 1, p. 45-57, 2005. http://dx.doi. org/10.1016/j.foodqual.2004.01.001

VIEIRA, A. O. et al. Análise da aceitação da sobremesa "láctea" de soja orgânica. In: CONGRESSO BRASILEIRO DE CIÊNCIA E TECNOLOGIA DE ALIMENTOS, 21., 2008, Belo Horizonte. Anais... Belo Horizonte, 2008.

WALKER, J. A. Development of low-fat sugar-free orange sherbet containing soy protein. 2002. $214 \mathrm{f}$. Dissertação (Mestrado em Ciência de Alimentos)-Louisiana State University and Agricultural and Mechanical College, Louisiana, 2002.

WHITE, D. et al. Sunflower-seed oil body emulsions: Rheology and stability assessment of a natural emulsion. Food Hydrocolloids, v. 22 , n. 7, p. 1224-1232, 2008. http://dx.doi.org/10.1016/j. foodhyd.2007.07.004 